\title{
Profesionalitas dan Pengawasan Dalam Mempengaruhi Kinerja Pegawai Dinas Pendidikan dan Kebudayaan Kabupaten Musi Banyuasin
}

\author{
Hosidin \\ Sekolah Tinggi Ilmu Ekonomi APRIN Palembang \\ Email: hosidin.68@gmail.com
}

\begin{abstract}
ABSTRAK
Penelitian ini bertujuan untuk mengetahui pengaruh profesionalitas dan pengawasan terhadap kinerja pegawai Dinas Pendidikan dan Kebudayaan Musi Banyuasin. Rumusan masalah bagaimana profesionalitas dan pengawasan mempengaruhi kinerja pegawai? Data yang digunakan dalam penelitian ini berupa data primer dari jawaban 73 responden. Metode penarikan sampel pada penelitian ini adalah Non probability sampling dengan tipe sampling jenuh. Model analisis yang digunakan regresi linear berganda dan melalui pengujian instrumen validitas dan reliabilitas.

Hasil pengujian regresi linear berganda untuk uji $\mathrm{F}$ menunjukkan terdapat pengaruh positif dan signifikan profesionalitas dan pengawasan terhadap kinerja sebesar 0,002. Variabel profesionalitas berpengaruh signifikan terhadap kinerja sebesar 0,032 dan pengawasan juga berpengaruh signifikan sebesar 0,027 terhadap kinerja pegawai Dinas Pendidikan dan Kebudayaan Kabupaten Musi Banyuasin. Adanya kesesuaian teori antar variabel dalam penelitian ini dan mendukung penelitian terdahulu. Peningkatan dan penurunan profesionalitas dan pengawasan terhadap kinerja pegawai.
\end{abstract}

Kata kunci: profesionalitas, pengawasan, kinerja.

\section{PENDAHULUAN}

Pengembangan Sumber Daya Manusia (SDM) yang berdasarkan pada profesionalisme dilakukan agar dapat memberikan hasil yang sesuai dengan tujuan dan sasaran organisasi dengan standar kinerja yang telah ditetapkan. Pegawai dalam suatu instansi merupakan salah unsur penting, pegawai penggerak utama yang menjalankan aktivitas kantor. Untuk itu pegawai profesional sangat dibutuhkan dalam suatu intansi, baik organisasi swasta maupun organisasi pemerintah. Pengelolaan kepegawaian atau yang lebih dikenal dengan istilah manajemen sumber daya manusia (SDM) harus dengan strategi yang tepat dan disesuaikan dengan peraturan dan norma yang berlaku di dalam organisasi (Dirjen Pemerintahan Umum,2005). Sebagai penggerak sektor pelayanan publik, pegawai harus profesional dan perlu adanya supervisi rutin pimpinan agar kinerja pegawai dapat tercapai maksimal.

Kinerja merupakan suatu kondisi yang harus diketahui dan dikonfirmasikan kepada pihak tertentu untuk mengetahui tingkat pencapaian hasil suatu instansi dihubungkan dengan visi yang diemban suatu organisasi atau perusahaan serta mengetahui dampak positif dan negatif dari suatu kebijakan operasional.

Kinerja dipengaruhi oleh banyak faktor, secara umum kinerja pegawai diartikan sebagai hasil yang ditampilkan oleh pegawai tersebut dalam pelaksanaan tugas sehari-hari. Mangkunegara (2015) menyatakan kinerja pegawai adalah prestasi kerja atau hasil kerja (output), baik kualitas maupun kuantitas yang dicapai 
oleh pegawai dalam periode tertentu, dalam melaksanakan tugas kerjanya, sesuai dengan tanggung jawab yang diberikan kepadanya. Untuk mengukur kinerja seseorang dapat dilihat pada situasi dan kondisi kerjanya sehari-hari.

Kinerja yang optimal tidak muncul secara otomatis, tetapi diiringi banyak faktor yang mempengaruhi, diantaranya adalah profesionalisme pegawai yang tinggi, peningkatan kinerja pegawai menjadi penting mengingat perubahan arah kebijakan pemerintah sebagaimana dikehendaki oleh semangat reformasi untuk lebih luas memberi ruang gerak dan peran serta yang lebih besar bagi masyarakat dalam kegiatan pemerintahan dan pembangunan, dimana pemerintah beserta aparaturnya lebih berperan sebagai fasilitator. Perubahan arah kebijakan ini membawa implikasi terhadap kemampuan profesionalisme pegawai dalam menjawab tantangan era globalisasi dalam menghadapi persaingan ketat dengan negara-negara lain didunia. Bertitik tolak dari pemikiran ini, maka peningkatan kinerja aparatur merupakan hal yang penting.

Tuntutan kinerja pelayanan publik kian hari kian tinggi, seiring dengan dinamika kehidupan masyarakat yang menghendaki pelayanan cepat, tepat dan dalam proses pelayanan yang nyaman, ramah, murah serta adil. Pelayanan publik merupakan ujung tombak penyelenggaraan pemerintahan dalam berhubungan pada masyarakat publik. Artinya kesuksesan pegawai dalam melakukan pelayanan publik juga merupakan tolak ukur kesuksesan dalam melaksanakan kegiatan pemerintah/negara.

Profesionalisme merupakan sifatsifat (kemampuan, kemahiran, cara pelaksanaan sesuatu dan lain-lain) sebagaimana yang sewajarnya terdapat pada atau dilakukan oleh seorang professional. Profesionalisme berasal dari pada profession yang bermakna berhubungan dengan profesi dan memerlukan kepandaian khusus untuk menjalankannya. Jadi, profesionalisme adalah tingkah laku, kepakaran atau kualitas dari seseorang yanag profesional (Anita, 2013).

Profesional itu berlaku untuk semua bagian mulai tingkat atas sampai tingkat bawah. Profesionalisme dapat diartikan sebagai suatu kemampuan dan keterampilan seseorang dalam melakukan pekerjaan menurut bidang dan tingkatan masing-masing. Profesionalisme menyangkut kecocokan antara kemampuan yang dimiliki oleh biroktasi dengan kebutuhan tugas, terpenuhi kecocokan antar kemampuan dengan kebutuhan tugas merupakan syarat terbentuknya aparatur yang profesional. Artinya keahlian dan kemampuan aparat merefleksikan arah dan tujuan yang ingin dicapai oleh sebuah organisasi (Setiawan, 2009).

Profesionalisme menyangkut kewenangan setiap individu untuk melakukan tugas atau mengambil keputusan sesuai dengan perannya dalam organisasi yang relevan dengan keahlian, pengetahuan dan kemampuan yang dimiliki. Profesionalisme yang dimiliki karyawan secara individual harus mampu mendukung pelaksanaan strategi organisasi dan mendukung setiap perubahan yang dilakukan manajemen. Dengan kata lain profesionalisme yang dimiliki individu dapat mendukung sistem kerja berdasarkan tim (Setiawan, 2009).

Pegawai yang profesional adalah seseorang yang menawarkan jasa atau layanan sesuai dengan protokol dan peraturan dalam bidang yang dijalaninya 
dan menerima gaji sebagai upah atas jasanya. Orang tersebut juga merupakan anggota suatu entitas atau organisasi yang didirikan sesuai dengan hukum di sebuah negara atau wilayah. Meskipun begitu, seringkali seseorang yang merupakan ahli dalam suatu bidang juga disebut "profesional" dalam bidangnya meskipun bukan merupakan anggota sebuah entitas yang didirikan dengan sah.

\begin{tabular}{ccc}
\multicolumn{2}{c}{ Kemampuan profesional dar } \\
pegawai Dinas Pendidikan dan
\end{tabular}

Kebudayaan Musi Banyuasin harus ditunjukkan ditengah dinamika tuntutan masyarakat atas maksimalisasi layanan publik. Untuk mengetahui pegawai profresionalitas pegawai dalam menjalankan tugas diperlukan adanya pengawasan yang tepat dari seorang pemimpin suatu organisasi atau institusi. Handoko (2013) menyatakan pengawasan atau supervisi merupakan satu proses untuk menetapkan pekerjaan apa yang sudah dilaksanakan. Selanjutnya Manullang (2013) menegaskan bahwa pengawasan mencakup upaya memeriksa apakah semua terjadi sesuai dengan rencana. Baik atau tidaknya kinerja pegawai tidak sekedar bergantung pada individu karyawan peranan pengawasan yang tepat turut memotivasi pegawai untuk meningkatkan kinerjanya. Pegawai yang profesional tidak terlepas dari disiplin kerja yang tinggi, biasanya pegawai yang disiplin akan profesional dalam melaksanakan tugasnya.

Penelitian ini ingin melihat research gap dengan penelitian sebelumnya yang dilakukan Istiariani (2018) yang menyatakan profesionalisme auditor berpengaruh terhadap kinerja auditor BPKP Jawa Tengah. Penelitian Lukas dkk (2017) yang menyatakan pengawasan tidak berpengaruh signifikan terhadap kinerja pegawai pada Badan Keuangan Kabupaten Minahasa Utara.

Rumusan masalah dalam penelitian ini adalah bagaimana profesionalitas dan pengawasan dalam mempengaruhi kinerja pegawai Dinas Pendidikan dan Kebudayaan Kabupaten Musi banyuasin.

\section{KAJIAN TEORI \\ Kinerja}

Handoko (2013), menyatakan kinerja merupakan suatu fungsi dari motivasi dan kemampuan untuk menyelesaikan tugas atau pekerjaan seseorang sepatutnya memiliki derajat kesediaan dan tingkat kemampuan tertentu. Kesediaan dan kemampuan seseorang tidaklah cukup efektif untuk mengerjakan sesuatu tanpa pemahaman yang jelas tentang apa yang akan dikerjakan dan bagaimana mengerjakannya. Dipertegas Mangkunegara (2015) Kinerja adalah hasil kerja secara kualitas dan kuantitas yang dicapai oleh seorang pegawai dalam melaksanakan tugasnya sesuai dengan tanggung jawab yang diberikan kepadanya. Kinerja juga dapat juga dikatakan sebagai hasil yang ditampilkan oleh Pegawai tersebut dalam pelaksanaan tugas sehari-hari. Jadi untuk mengukur kinerja seseorang dapat dilihat pada sitiasi dan kondisi kerjanya sehari-hari. Selanjutnya dipertegas Veithzal (2011) kinerja adalah suatu tampilan keadaan secara utuh atas perusahaan selama periode waktu tertentu, merupakan hasil atas prestasi yang dipengaruhi oleh kegiatan operasional perusahaan dalam memanfaatkan sumber-sumber daya yang dimiliki.

Selanjutnya Mangkunegara (2005:67), menyatakan indikator yang dapat digunakan untuk mengukur kinerja 
pegawai adalah dengan melihat hasil kerjanya secara kualitas dan kuantitas yang dicapai oleh seorang pegawai dalam melaksanakan tugasnya sesuai dengan tanggung jawab yang diberikan kepadanya yaitu berupa 1) kualitas kerja, pegawai yang memiliki kinerja yang baik, maka dapat dilihat dari kualitas kerja, akurasi kerja, dan marginal kesalahan. 2)kuantitas kerja, pegawai selalu berusaha untuk menyelesaikan tugas dengan hasil yang benar, maksimal, dan tepat waktu. 3) tanggung jawab, egawai bertanggung jawab dalam menyelesaikan tugas-tugas, memiliki rencana kerja yang jelas, berusaha untuk merealisasikan rencana kerja.

\section{Profesionalisme}

Profesional berasal dari akar kata "professional" yang jika ditilik dalam kamus Webster dijelaskan sebagai "learned vocation" atau "Vocation that requires learning rather than work with the hands" atau "one who engages in a learned vocatioral" ( 2011). Dipertegas Mudlofir (2012) profesional adalah suatu sebutan terhadap kualitas sikap para anggota suatu profesi serta derajat pengetahuan dan keahlian yang mereka mililki untuk melakukan tugas-tugasnya. Didukung pernyataan Hikmat (2011) bahwa seseorang dianggap sebagai tenaga profesional apabila dalam mengerjakan tugasnya, ia selalu berpegang teguh pada etika kerja, independen (bebas dari tekanan pihak luar), cepat (produktif), tepat (efektif), efisien dan inovatif.

Gambaran seseorang yang profesional dalam profesi dicerminkan dalam lima dimensi profesionalisme atau lebih dikenal dengan dimensi profesional Hall, yaitu sebagai berikut:

1) Pengabdian pada pekerjaan
Dapat dicerminkan dari dedikasi dengan menggunakan pengetahuan dan kecakapan yang dimiliki serta keteguhan untuk tetap melaksanakan pekerjaan meskipun imbalan ekstrinsik kurang. Sikap ini adalah ekspresi dari pencurahan diri yang total terhadap pekerjaan.

2) Kewajiban sosial

Merupakan pengertian tentang pentingnya peranan profesi serta manfaat yang diperoleh baik masyarakat maupun kalangan profesional lainnya karena adanya pekerjaan tersebut.

3) Kemandirian

Diartikan sebagai suatu konsep bahwa seorang yang profesional harus mampu membuat keputusan sendiri tanpa tekanan dari pihak lain (pemerintah, klien dan mereka yang bukan anggota profesi). Setiap ada campur tangan dari luar dianggap sebagai hambatan kemandirian secara profesional.

4) Keyakinan terhadap pekerja

Merupakan suatu keyakinan bahwa yang paling berwenang menilai apakah suatu pekerjaan yang dilakukan profesional atau tidak adalah rekan sesama pekerja, bukan pihak luar yang tidak mempunyai kompetensi dalam bidang ilmu dan pekerjaan tersebut.

5) Hubungan dengan sesama pekerjaan Adalah dengan menggunakan ikatan pekerjaan sebagai acuan, termasuk di dalamnya organisasi formal dan kelompok kolega informal sebagai ide utama dalam melaksanakan pekerjaan.

\section{Pengawasan}

Rivai (2011) menyatakan pengawasan kerja merupakan proses berkelanjutan untuk menilai kualitas kerja 
pegawai dan usaha untuk memperbaiki unit kerja pegawai dalam suatu organisasi. Melalui pengawasan pemimpin dapat mengetahui apakah pekerjaan itu sudah selesai atau belum dengan uraian kerja yang telah disusun sebelumnya. Dipertegas Handoko (2013) pengawasan merupakan sautu proses untuk menetapkan pekerjaan apa yang sudah dilaksanakan. Di pertegas pendapat Manullang (2008) yang menyatakan bahwa pengawasan mencakup upaya memeriksa apakah semua terjadi sesuai dengan rencana. Pengertian lain pengawasan adalah kegiatan memberikan pengamatan, dan pengevaluasian kegiatan dalam suatu organisasi agar tujuan yang telah ditetapkan dapat berjalan dengan lancar (Haris, 2004).

Pengawasan mempunyai tujuan, Manullang (2013) menyatakan tujuan dari sebuah pengawasan adalah untuk mencegah atau memperbaiki kesalahan, penyimpangan dan penyelewengan yang tidak sesuai dengan tugas dan tanggung jawab yang telah ditentukan. Pengawasan bukan diartikan sebagai pencarian kesalahan orang lain, akan tetapi untuk mencari kebenaran terhadap hasil pekerjaan yang dilakukan. Pengawasan dapat meminimalisir kesalahan agar tidak menjadi sebuah kesalahan besar.

\section{METODE PENELITIAN}

Penelitian ini merupakan penelitian asosiatif yaitu penelitian yang bertujuan untuk melihat pengaruh variabel independen dan variabel dependen serta dilengkapi dengan hipotesis.

\section{Populasi dan Sampel}

Kelompok populasi (Population frame) merupakan kumpulan semua elemen dalam populasi di mana sampel diambil. Populasi dalam penelitian ini adalah pegawai negeri sipil dari 6 bidang di Dinas Pendidikan dan Kebudayaan sebanyak 73 orang. Sampel adalah bagian dari jumlah dan karakteristik yang dimiliki oleh populasi. Jika populasi kurang dari 100 diambil semua, sedangkan bila lebih dari 100 dapat diambil antara 10\% - 15\% atau 20\%-25\% lebih, setidak-tidaknya tergantung dari kemampuan peneliti. Mengingat besar populasi dalam penelitian ini kurang dari 100, maka seluruh responden dalam ini yang berjumlah 73 orang dijadikan sampel. Metode penarikan sampel pada penelitian ini adalah Non probability sampling dengan tipe sampling jenuh yaitu tehnik penentuan sampel bila semua anggota populasi digunakan sebagai sampel. Desain penelitian menggambarkan hubungan kausal variabel Profesionalitas $\left(\mathrm{X}_{1}\right)$ dan Pengawasan $\left(\mathrm{X}_{2}\right)$ terhadap kinerja pegawai (Y) seperti di bawah ini:

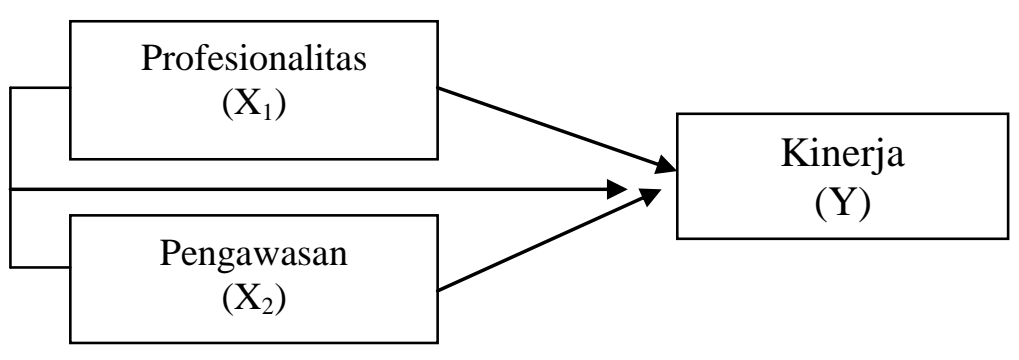


Model analisis dalam penelitian ini menggunakan analisis regresi linear berganda yang dirumuskan sebagai berikut:

Keterangan:

$$
\mathrm{Y}=\mathrm{a}+\mathrm{b}_{1} \mathrm{X}_{1}+\mathrm{b}_{2} \mathrm{X}_{2}+\mathrm{e}
$$

$\mathrm{X} 1=$ Profesionalitas

$\mathrm{X} 2$ = Pengawasan

$\mathrm{Y}=$ Kinerja pegawai

$\mathrm{e} \quad=$ error term

Hipotesis dalam penelitian ini adalah sebagai berikut:

H1: Kompetensi profesional berpengaruh signifikan terhadap kinerja dosen

$\mathrm{H} 2$ : Iklim organisasi berpengaruh signifikan terhadap kinerja dosen

H3:Kompetensi profesional dan iklim organisasi berpengaruh Signifikan terhadap kinerja dosen.

\section{HASIL DAN PEMBAHASAN}

Hasil pengujian validitas dan reliabilitas untuk butir pertanyaan yang mengukur masing-masing variabel profesionalitas dan pengawasan serta kinerja menunjukkan nilai Corrected ItemTotal Correlation > 0,361 untuk sampel pengujian $\mathrm{n}=30$ artinya semua data yang tersebar melalui angket dinyatakan valid.
Untuk nilai reliabel masing-masing variabel diperoleh nilai > nilai standar 0,7 maka semua data variabel penelitian dinyatakan reliabel. Uji normalitas dalam penelitian ini dilakukan untuk mengetahui apakah suatu distribusi data normal atau mendekati normal. Hasil pengujian dapat di lihat pada Tabel berikut:

Tabel 1

Hasil Uji Normalitas Data

\begin{tabular}{|ll|r|r|r|}
\hline & & Profesionalitas & Pengawasan & \multicolumn{1}{c|}{ Kinerja } \\
\hline $\mathrm{N}$ & & 73 & 73 & 73 \\
Normal Parameters ${ }^{\mathrm{a}, \mathrm{b}}$ & Mean & 2,9954 & 2,9082 & 2,7536 \\
& Std. Deviation & 0,47144 & 0,34214 & 0,56118 \\
Most Extreme Differences & Absolute & 0,058 & 0,087 & 0,052 \\
& Positive & 0,047 & 0,087 & 0,030 \\
& Negative & $-0,058$ & $-0,052$ & $-0,052$ \\
Kolmogorov-Smirnov Z & & 0,368 & 0,457 & 0,536 \\
Asymp. Sig. (2-tailed) & & 0,524 & 0,367 & 0,235 \\
\hline
\end{tabular}

Sumber: Hasil pengolahan data, 2018

Hasil pengujian normalitas dengan test of normality Kolmogorov Smirnov diperoleh nilai Asymp.sig. (2-tailed) $>0,05$ artinya semua data terdistribusi normal. 
Tabel 2.

Hasil Uji Regresi Linear Berganda

\begin{tabular}{|c|c|c|c|}
\hline \multirow[b]{2}{*}{ Model } & \multicolumn{2}{|c|}{ Unstandardized Coefficients } & $\begin{array}{l}\text { Standardized } \\
\text { Coefficients }\end{array}$ \\
\hline & B & Std. Error & Beta \\
\hline 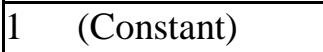 & 1,265 & 0,399 & \\
\hline Profesionalitas & 0,537 & 0,095 & 0,2 \\
\hline Pengawasan & 0,255 & 0,073 & 0,19 \\
\hline
\end{tabular}

Sumber: Hasil pengolahan data, 2018

Hasil perhitungan pada Tabel 2 menunjukkan constanta sebesar 1,265 artinya dengan ada atau tanpa profesionalitas dan pengawasan kinerja tetap terbentuk sebesar 1,265. Nilai profesionalitas dan pengawasan sebesar 0,537 dan 0,255 menunjukkan bahwa penurunan dan peningkatan setiap satu satuan variabel bebas dapat meningkatkan dan menurunkan kinerja pegawai sebesar satu satuan skor.

Hasil perhitungan untuk uji multikolinearitas diperoleh nilai tolerance variabel profesionalitas sebesar 0,932>0,10; dan variabel pengawasan sebesar 0,995 > 0,10. Nilai VIF variabel profesionalitas sebesar $1,208<10$ dan nilai variabel profesionalitas sebesar 1,205 < 10. Dari perhitungan diatas dapat disimpulkan datadata dalam penelitian ini tidak terdeteksi mengandung multikolinearitas.

Uji F digunakan untuk menguji pengaruh variabel profesionalitas dan pengawasan terhadap kinerja pegawai, hasil penghitungan dapat di lihat pada Tabel berikut:

Tabel 3.

Hasil Hipotesis Uji F

\begin{tabular}{|ll|r|r|r|c|c|}
\hline Model & Sum of Squares & Df & Mean Square & F & Sig. \\
\hline 1 & Regression & 2,981 & 2 & 0,928 & 4,219 & $0,002^{2}$ \\
Residual & 15,056 & 70 & 0,176 & & \\
Total & 19,091 & 72 & & & \\
\hline
\end{tabular}

Sumber: Hasil pengolahan data, 2018

Dari hasil penghitungan regresi linear berganda diperoleh nilai sig $\mathrm{F}$ $(0,002)<\operatorname{Sig} \alpha(0,05)$ maka $\mathrm{H}_{0}$ ditolak artinya profesionalitas dan pengawasan mempunyai pengaruh signifikan terhadap kinerja pegawai. Hasil perhitungan untuk uji t atau uji koefisien regresi dapat di lihat pada Tabel berikut ini:

Tabel 4.

Hasil Uji Hipotesis Uji t

\begin{tabular}{|l|r|r|}
\hline \multicolumn{1}{|c|}{ Model } & \multicolumn{1}{|c|}{} \\
\hline (Constant) & t & \multicolumn{1}{c|}{ Sig. } \\
Profesionalitas & 3,466 & 0,001 \\
Pengawasan & 2,564 & 0,032 \\
\hline
\end{tabular}


Sumber: Hasil pengolahan data, 2018

Berdasarkan hasil perhitungan uji koefisien regresi pada Tabel 4 variabel profesionalitas diperoleh nilai sig t sebesar $0,032<\operatorname{sig} \alpha(0,05)$, maka H0 ditolak artinya terdapat pengaruh positif dan signifikan profesionalitas terhadap kinerja. Variabel pengawasan diperoleh nilai sig $\mathrm{t}$ sebesar $0,027<\operatorname{sig} \alpha(0,05)$, maka $\mathrm{H} 0$ ditolak artinya pengawasan mempunyai pengaruh positif dan signifikan terhadap kinerja pegawai.

Pengaruh Profesionalitas terhadap Kinerja Pegawai Dinas Pendidikan dan Kebudayaan Kabupaten Musi Banyuasin

Profesionalitas pegawai sudah cukup baik namun beberapa pegawai kurang memiliki kecakapan untuk mengetahui tugas sesuai dengan job description. Responden kurang setuju dengan pernyataan bahwa mereka bekerja dengan independen dan tidak terikat pada atasan, jabatan atau kepentingan pribadi, menurut responden karena ada beberapa kelompok yang memiliki kedekatan kerja dan menjadi kepercayaan pimpinan karena dianggap ahli dalam bidangnya menurut pimpinan. Pegawai juga kurang memiliki keberanian mengemukakan pendapat terkait biokrasi yang rumit dalam pelayanan publik, sehingga kelemahan dalam pelayanan publik harus diatasi oleh pegawai di lapangan. Responden kurang setuju dengan pendapat bahwa koordinasi kerja antar pegawai sudah berjalan dengan baik sesuai dengan program kerja yang ada. Hal di atas berdampak pada kinerja pegawai hal ditunjukkan masih terdapat yang belum mampu menterjemahkan dan memahami instruksi atasan sehingga hasil pekerjaan belum benar sesuai dengan ketentuan. Terdapat responden yang menyatakan pegawai belum memahami tugas dan fungsinya misalnya pegawai sering meninggalkan kantor pada saat jam kantor untuk kepentingan pribadi.

Profesionalitas pegawai Dinas pendidikan dan kebudayaan sudah cukup baik namun masih memerlukan peningkatan profesionalitas pegawai dengan cara memahami job deskription yang diberikan. Dalam pelayanan publik tidak boleh didorong pada azas kepentingan pada individu atau kelompok tertentu, pelayanan harus maksimal dan merata. Gambaran pegawai yang profesional dapat tercermin pada lima dimensi profesional Hall yaitu pengabdian pada pekerjaan, kewajiban sosial pegawai terhadap pekerjaan, kemandirian, dan keyakinan pada pekerjaan. Seorang pegawai harus memiliki kompetensi pribadi dan kompetensi profesional, jika menyeimbangkan keduanya maka seorang pekerja dapat bekerja secara baik dan benar sesuai dengan keahlian dan profesinya (profesional).

\section{Pengaruh Pengawasan terhadap Kinerja Pegawai Dinas Pendidikan dan Kebudayaan kabupaten Musi Banyuasin}

Pengawasan di Dinas Pendidikan dan Kebudayaan sudah cukup baik, atasan melakukan pengamatan dan menilai perilaku pegawai secara rutin. Pengawasan dapat membuat pegawai mampu menyelesaikan pekerjaan yang selama ini tertunda. Ketegasan atasan dalam memberikan batas waktu penyelesaian pekerjaan, namun gaya kepemimpinan kepala dinas yang tegas dalam memberikan batas waktu dalam menyelesaikan pekerjaan lama kelamaan menimbulkan suasana yang tidak 
harmonis, sehingga pegawai bekerja terasa monoton dan kaku.

Untuk mengatasi kelemahan di atas kepala dinas harus lebih komunikatif dan lakukan pendekatan pada pegawai. Wujudkan suasana harmonis di lingkungan kantor agar pegawai dapat bekerja dengan nyaman. Berikan motivasi berupa penghargaan bagi pegawai berprestasi, pengawasan yang berwujud berupa pengembangan karir pegawai, sehingga pegawai bekerja dengan maksimal. Setiap pekerjaan hendaknya melibatkan melibatkan seluruh pegawai secara merata agar pegawai merasa dibutuhkan dan tidak menimbulkan kecemburuan sosial.

Mengacu pada pendapat Manullang (2013) yang menyatakan bahwa pengawasan mencakup upaya memeriksa apakah semua terjadi sesuai dengan rencana. Pengawasan merupakan kegiatan memberikan pengamatan dan pengevaluasian kegiatan dalam suatu organisasi agar tujuan yang ditetapkan dapat berjalan sesuai rencana. Mengacu pada kriterianya sebuah pengawasan haruslah akurat, tepat waktu, objektif dan menyeluruh, terpusat pada titik pengawasan strategi dan sebuah pengawasan harus dapat diterima oleh seluruh anggota organisasi.

\section{PENUTUP}

\section{Simpulan}

Berdasarkan hasil penelitian yang dilakukan, maka dapat disimpulkan bahwa terdapat pengaruh positif dan signifikan profesionalitas dan pengawasan secara simultan danparsial terhadap kinerja pegawai Dinas Pendidikan dan Kebudayaan Kabupaten Banyuasin

\section{Rekomendasi}

Profesionalitas pegawai Dinas pendidikan dan kebudayaan sudah cukup baik namun masih memerlukan peningkatan profesionalitas pegawai dengan cara memahami job deskription yang diberikan. Dalam pelayanan publik tidak boleh didorong pada azas kepentingan pada individu atau kelompok tertentu, pelayanan harus maksimal dan merata. Untuk mengatasi masalah pengawasan kepala dinas harus lebih komunikatif dan lakukan pendekatan pada pegawai. Berikan motivasi berupa penghargaan bagi pegawai berprestasi. Pengawasan yang berwujud berupa pengembangan karir pegawai, sehingga pegawai dapat bekerja dengan baik dan cepat. Pekerjaan hendaknya melibatkan melibatkan seluruh pegawai secara merata agar pegawai merasa dibutuhkan.

\section{DAFTAR PUSTAKA}

Arikunto, Suharsimi (2013). Prosedur Penelitian Suatu Pendekatan Praktik. Cetakan ke-15. Bandung: Rineka Cipta.

Anita dkk. (2013). Peran Diklat Dalam Peningkatan Kualitas SDM Di Badan Kepegawaian Daerah Provinsi Jawa Tengah Meningkatkan Kualitas SDM. hlm 1:7-8

Budi Setiawan (2009). Analisis Pengaruh Profesionalisme Petugas Pajak Terhadap Kinerja Organisasi Kantor Pelayanan Pajak Pontianak. Tesis Tidak Diterbitkan. Pontianak : Program Magister Manajemen, Universitas Taruma Negara. 
Handoko, T, Hani (2013). Manajemen Personalia dan SDM. Yogyakarta: BPFE

Hikmat. (2011). Manajemen Pendidikan. (cet.2). Bandung, Indonesia: Pustaka Setia.

Istiariani, Irma (2018). Pengaruh Independensi, Profesionalisme dan Kompetensi terhadap Kinerja Auditor BPKP (Studi Kasus pada Auditor BPKP Jateng). Jurnal Pemikiran Islam. Vol.19(1) Maret 2018. Hal: 63-88. Diakses: jurnalnasional.ump.ac.id.download.

Lukas, M. Tewal, Bernhard. Walangitan (2017). Pengaruh Pengawasan, Kepemimpinan, dan Kompensasi terhadap Kinerja Pegawai pada Badan Pengelola Keuangan dan Barang Milik Daerah Kabupaten
Minahasa Utara. Jurnal EMBA. Vol.5(2) Juni 2017. Hal: 1921-1928. Diakses:https://media.neliti.com.pub lication.

Mangkunegara, Prabu, Anwar (2015). Manajemen SDM Perusahaan. Bandung: Remaja Rosdakarya.

Manullang, M (2013). Manajemen Sumber Daya Manusia. Bandung:Ciptapustaka Media Perintis.

Mudlofir, Ali. (2012). Pendidik Profesional. (cet.1). Jakarta, Indonesia: Rineka Cipta.

Rivai, Veitzhal \& Ella, Jauvani Sagala.(2011). Manajemen Sumber Daya Manusia Untuk Perusahaan : Dari Teori ke Praktik. Jakarta: RajaGrafindo Persada 